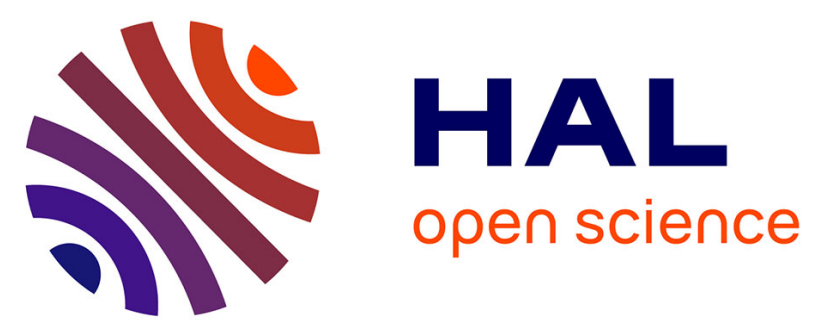

\title{
CNS SPECIES AND ANTIMICROBIAL RESISTANCE IN CLINICAL AND SUBCLINICAL BOVINE MASTITIS
}

K. Persson Waller, A. Aspán, A. Nyman, Y. Persson, U. Grönlund Andersson

\section{- To cite this version:}

K. Persson Waller, A. Aspán, A. Nyman, Y. Persson, U. Grönlund Andersson. CNS SPECIES AND ANTIMICROBIAL RESISTANCE IN CLINICAL AND SUBCLINICAL BOVINE MASTITIS. Veterinary Microbiology, 2011, 152 (1-2), pp.112. 10.1016/j.vetmic.2011.04.006 . hal-00719073

\section{HAL Id: hal-00719073 \\ https://hal.science/hal-00719073}

Submitted on 19 Jul 2012

HAL is a multi-disciplinary open access archive for the deposit and dissemination of scientific research documents, whether they are published or not. The documents may come from teaching and research institutions in France or abroad, or from public or private research centers.
L'archive ouverte pluridisciplinaire HAL, est destinée au dépôt et à la diffusion de documents scientifiques de niveau recherche, publiés ou non, émanant des établissements d'enseignement et de recherche français ou étrangers, des laboratoires publics ou privés. 


\section{Accepted Manuscript}

Title: CNS SPECIES AND ANTIMICROBIAL RESISTANCE IN CLINICAL AND SUBCLINICAL BOVINE MASTITIS

Authors: K. Persson Waller, A. Aspán, A. Nyman, Y. Persson,

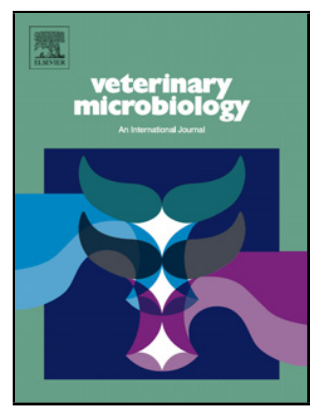
U. Grönlund Andersson

PII:

DOI:

Reference:

S0378-1135(11)00220-3

VETMIC 5269

To appear in: $\quad$ VETMIC

Received date: $\quad$ 25-2-2011

Revised date: $\quad 1-4-2011$

Accepted date: $\quad$ 6-4-2011

Please cite this article as: Persson Waller, K., Aspán, A., Nyman, A., Persson, Y., Grönlund Andersson, U., CNS SPECIES AND ANTIMICROBIAL RESISTANCE IN CLINICAL AND SUBCLINICAL BOVINE MASTITIS, Veterinary Microbiology (2010), doi:10.1016/j.vetmic.2011.04.006

This is a PDF file of an unedited manuscript that has been accepted for publication. As a service to our customers we are providing this early version of the manuscript. The manuscript will undergo copyediting, typesetting, and review of the resulting proof before it is published in its final form. Please note that during the production process errors may be discovered which could affect the content, and all legal disclaimers that apply to the journal pertain. 
1 CNS SPECIES AND ANTIMICROBIAL RESISTANCE IN CLINICAL AND

2 SUBCLINICAL BOVINE MASTITIS

3

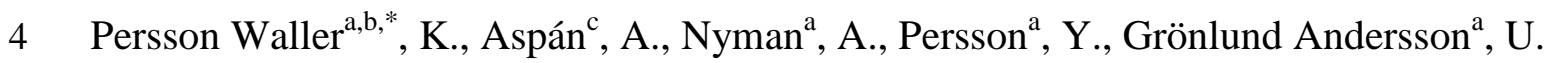

$5 \quad{ }^{\mathrm{a}}$ Department of animal health and antimicrobial strategies, National Veterinary Institute,

6 SE-751 89 Uppsala, Sweden

$7 \quad{ }^{b}$ Department of clinical sciences, Swedish University of Agricultural Sciences, SE-750

$8 \quad 07$ Uppsala, Sweden

$9{ }^{c}$ Department of bacteriology, National Veterinary Institute, SE-751 89 Uppsala, Sweden

$11 *$ Corresponding author:

12 Karin Persson Waller

13 Department of animal health and antimicrobial strategies

14 National Veterinary Institute

15 SE-751 89 Uppsala, Sweden

16 Telephone: +4618 674000

17 Telefax: +4618309162

18 E-mail: $\underline{\text { Karin.Persson-Waller@sva.se }}$

20 Abstract

21 Coagulase-negative staphylococci (CNS) are often associated with bovine mastitis.

22 Knowledge about the relative importance of specific CNS species in different types of mastitis, and differences in antimicrobial resistance among CNS species is, however, scarce. Therefore, the aims of this study were to compare prevalence and antimicrobial susceptibility of CNS species in clinical and subclinical mastitis using material from 
two national surveys. Overall, S. chromogenes and S. epidermidis were the most common CNS species found followed by $S$. simulans and S. haemolyticus. $S$. epidermidis was significantly more prevalent in subclinical than in clinical mastitis, and a similar trend was observed for S. saprophyticus, while $S$. hyicus was significantly more common in clinical mastitis. The prevalence of $\beta$-lactamase producing isolates varied markedly between CNS species, and was significantly higher in S. epidermidis and S. haemolyticus ( $40 \%)$, than in S. simulans and S. chromogenes where none or a few of the isolates produced $\beta$-lactamase. Resistance to more than one antimicrobial substance occurred in $9 \%$ and $7 \%$ of the clinical and subclinical isolates, respectively. In conclusion, the distribution of CNS species differed between clinical and subclinical mastitis indicating inter-species variation of pathogenicity and epidemiology. Overall, the prevalence of antimicrobial resistance was low, but some variation between CNS species was observed.

Keywords: bovine mastitis, CNS species, antimicrobial susceptibility 


\section{Introduction}

44 Coagulase-negative staphylococci (CNS) are associated with bovine intra-mammary infections (IMI) and may cause both subclinical and clinical mastitis. In most cases, however, the inflammatory reaction is relatively mild. The prevalence of CNS IMI may vary markedly between regions and countries, but is in most cases lower in studies on clinical than in studies on subclinical mastitis (for review see Pyörälä and Taponen, 2009). In national Swedish surveys on clinical (Ericsson Unnerstad et al., 2009) and subclinical (Persson Y., unpublished results) mastitis the CNS prevalence was $6 \%$ and $17 \%$, respectively.

The control of CNS mastitis is complicated by the heterogeneity of this bacterial group.

Today more than 15 CNS species have been identified in association with bovine IMI. Species identification of CNS can be performed using phenotyping or genotyping, but genotyping is nowadays considered superior to phenotyping (Zadoks and Watts, 2009).

The distribution of species varies between studies, but in recent studies using genotyping for CNS speciation S. chromogenes, S. epidermidis, S. haemolyticus, $S$. simulans and S. xylosus are commonly found (Taponen et al., 2006; Taponen et al., 2008; Capurro et al., 2009; Sampimon et al., 2009; Perry et al., 2010). Knowledge about the relative prevalence of specific CNS species in different types of mastitis is, however, scarce. In a Finnish study comparing prevalences of CNS species among cases of CNS in clinical and subclinical mastitis, Taponen et al. (2006) found no difference in the prevalences of $S$. chromogenes and S. simulans. To our knowledge, however, similar studies have not been performed on national level.

66 
67 Antimicrobials are an important tool in mastitis control programs. Therefore,

surveillance of antimicrobial resistance is important to ensure optimal results of antimicrobial use and minimize the risk for development and spread of antimicrobial resistance. Very few studies have investigated differences in antimicrobial resistance among CNS species identified by genotyping (Sampimon, 2009), and no study has compared antimicrobial resistance in CNS species found in clinical and subclinical mastitis.

The aims of this study were to compare prevalence and antimicrobial susceptibility of CNS species in clinical and subclinical mastitis using material from two national surveys.

\section{Material and methods}

\subsection{CNS isolates and bacteriological analyses}

CNS isolates included in the study originated from national surveys on prevalence of udder pathogens in acute clinical mastitis (Ericsson Unnerstad et al., 2009), and subclinical mastitis (Persson Y., unpublished). In Ericsson Unnerstad et al. (2009), milk samples were collected by field veterinarians distributed all over the country. The number of cases per practice was proportional to the number of dairy cows in the county. In each practice, cases were enrolled in order of appearance until the sampling quota was filled. Only cases of acute clinical mastitis given specific inclusion criteria were eligible for sampling. The enrolment of veterinary practices, numbers of cases per practice and selection of cases were similar in the study on subclinical mastitis. In the latter study aseptic quarter milk samples $(\mathrm{CMT}>2$; scale 1-5) were taken from one cow 
with new infection and one cow with chronic infection in each herd according to criteria specified in Table 1.

Milk samples were directly cultured $(10 \mu \mathrm{l})$ on $5 \%$ bovine blood agar plates (Oxoid Ltd., Cambridge, UK). The agar plates were incubated at $37^{\circ} \mathrm{C}$ for $16-24 \mathrm{~h}$. The isolates were identified as CNS by phenotypic appearance and negative reaction in the tube coagulase test according to recommendations by the National Mastitis Council (Hogan et al., 1999). Isolates were stored at $-20^{\circ} \mathrm{C}$ in trypticase soy broth (Oxoid Ltd) containing $15 \%$ glycerol. Species differentiation of CNS isolates was made by sequencing part of the tuf gene as previously described (Capurro et al., 2009).

Antimicrobial susceptibility for the following substances was investigated; penicillin, oxacillin, erythromycin, tetracycline, gentamicin, ciprofloxacin and trimethoprim.

Minimum inhibitory concentrations were determined by using a microdilution method (Bengtsson et al., 2009). Examination of $\beta$-lactamase production was performed using the "clover-leaf" method (Bryan and Godfrey, 1991). For quality control, the strains $S$. aureus ATCC 29213 and S. aureus ATCC 25923 were used. For testing of oxacillin susceptibility $2 \% \mathrm{NaCl}$ was added to the broth and isolates with a MIC for oxacillin $>1$ $\mathrm{mg} / \mathrm{L}$ were examined for presence of the $m e c A$-gene by PCR according to Smyth et al. (2001).

Isolates were classified as susceptible or resistant based on species-specific epidemiological cut-off values issued by European Committee on Antimicrobial Susceptibility Testing (EUCAST) (http|lwww.eucast.org). For trimethoprim, a cut-off for CNS was not available. Therefore the cut-off for $S$. aureus was used (>2 mg/L). 
116 Classification of staphylococci as resistant to penicillin or oxacillin was based on

117 production of $\beta$-lactamase and presence of $m e c A$ gene, respectively.

\subsection{Statistical analyses}

Differences in prevalence were investigated using the Chi-square or Fisher's exact tests

(Statistica 6.0, StatSoft, Inc., Tulsa, OK, USA). All CNS isolates (62 clinical; 98

subclinical) were included in the data set when comparing prevalence of CNS between clinical and subclinical cases. The isolates originated in 55 and 94 herds, respectively.

When evaluating the distribution of CNS species and antimicrobial resistance (positive $(\beta+)$ or negative $(\beta-)$ in the $\beta$-lactamase test) only the first isolate per CNS species and herd was included in the clinical $(n=56)$ and subclinical $(n=94)$ group. Thus, 4 subclinical cases $(1$ S. chromogenes $(\beta-), 1$ S. epidermidis $(\beta+), 1$ S. saprophyticus $(\beta+)$, $1 S$. simulans $(\beta-))$ were excluded from that evaluation. However, when comparing new and chronic subclinical cases, and in the descriptive statistics given in the tables, all isolates $(n=98)$ were included. Statistical evaluation was not performed when the total number of isolates in the two groups compared was less than 5 .

\section{Results}

CNS was significantly $(\mathrm{P}<0.001)$ more prevalent in subclinical than in clinical cases of mastitis (Table 2). Among cases with specific infection (i.e. excluding samples with no growth and contaminated samples), CNS was also significantly ( $\mathrm{P}=0.022)$ more common in new than in chronic subclinical mastitis (Table 2).

In total, $14 \mathrm{CNS}$ species were identified, 9 of those in clinical and 12 in subclinical cases of mastitis (Table 3). Seven species (S. chromogenes, S. epidermidis, $S$. 
haemolyticus, S. hyicus, S. simulans, S. warneri/pasteuri, S. xylosus) were found in both groups, while 2 species (S. aureus (coagulase-negative), S. lentus) were found only in clinical cases, and 5 species (S. arlettae, S. gallinarum, S. pseudintermedius, $S$. saprophyticus, $S$. spp.) only in subclinical cases. S. chromogenes, $S$. simulans and $S$. haemolyticus were the most common findings in clinical mastitis, while S. epidermidis followed by $S$. chromogenes, S. simulans and S. haemolyticus were most common in subclinical mastitis (Table 3$)$. S. epidermidis $(\mathrm{P}<0.001)$ was significantly more prevalent in subclinical than in clinical mastitis, and a similar trend was observed for $S$. saprophyticus $(\mathrm{P}=0.057)$. The opposite was the case for S. hyicus $(\mathrm{P}<0.001)$, while no significant difference $(\mathrm{P}>0.05)$ between clinical and subclinical cases was found for $S$. chromogenes, S. haemolyticus, S. simulans, S. warnerii/pasteuri and S. xylosus. The distribution of CNS species did not differ significantly $(\mathrm{P}>0.05)$ between cases of new and chronic subclinical mastitis.

$\beta$-lactamase production $(\beta+)$ was significantly more common $(\mathrm{P}=0.003)$ in subclinical cases than in clinical cases (Table 3), but new and chronic subclinical mastitis did not differ significantly $(\mathrm{P}>0.05)$. The proportion of $\beta+$ isolates varied markedly between CNS species (Table 3). Overall among species with at least 10 isolates, the prevalence of $\beta+$ isolates was significantly higher $(\mathrm{P}<0.004)$ in $S$. epidermidis and $S$. haemolyticus (just over 40\%), compared to S. simulans and S. chromogenes where none or a few of the isolates were $\beta+$. Within these 4 species the prevalence of $\beta+$ did not differ significantly between clinical and subclinical cases. Among CNS species found less frequently, the proportion of $\beta+$ was very high (86\%) in S. saprophyticus, and high (40$67 \%$ ) also in S. warneri/pasteuri and S. xylosus, while none of the S. hyicus isolates was $\beta+$. 
167 Resistance to more than one antimicrobial substance occurred in $5(8.9 \%)$ and $7(6.7 \%)$ of the clinical and subclinical isolates, respectively. Among the clinical isolates, 3 (one each of S. aureus, S. haemolyticus and S. xylosus) were resistant to penicillin and tetracycline, gentamicin or erythromycin. One isolate (S. lentus) was resistant to erythromycin and tetracycline, and 1 isolate (S. epidermidis) to penicillin, oxacillin and tetracycline. The latter isolate was also methicillin resistant (mecA gene positive by PCR). Among subclinical isolates, 4 (1 S. arlettae, 3 S. haemolyticus) were $\beta+$ and resistant to trimethoprim, 1 (S. cohnii) was $\beta+$ and resistant to tetracycline, 1 ( $S$. epidermidis) was $\beta+$ and resistant to erythromycin, and 1 (S. epidermidis) was $\beta+$ and resistant to erythromycin and tetracycline. Ten (6 S. saprophyticus, $2 S$. gallinarum, $1 S$. warneri and $1 \mathrm{~S}$. haemolyticus) isolates had a MIC $>2 \mathrm{mg} / \mathrm{L}$ for oxacillin, but none of the isolates was positive for the mecA gene. All 13 S. simulans isolates, and 13 of $14 S$. haemolyticus isolates were resistant to trimethoprim, i.e. MIC $>2 \mathrm{mg} / \mathrm{L}$. These 26 isolates constituted $79 \%$ of all trimethoprim resistant CNS isolates.

\section{Discussion}

Overall, CNS was more common in subclinical than in clinical cases of mastitis, which is in line with earlier studies on either clinical or subclinical mastitis (for review see Pyörälä and Taponen, 2009). Very few studies have, however, presented data on both subclinical (24\%) mastitis (Koivula et al., 2007). We also found that CNS was more prevalent in new than in chronic subclinical cases. The reason for this is not clear, but it may indicate that transient CNS infections are relatively common. 
192 Overall, S. chromogenes and S. epidermidis were the most common CNS species found followed by S. simulans and S. haemolyticus. These species were also found in varying proportions in previous studies based on genotyping (Taponen et al., 2006; Taponen et al., 2008; Capurro et al., 2009; Sampimon et al., 2009; Perry et al., 2010). The distribution of CNS species differed somewhat between clinical and subclinical mastitis.

S. hyicus was more common among clinical cases, while $S$. epidermidis and $S$. saprophyticus (tendency) were more common among subclinical cases. In line with Taponen et al. (2006) the prevalences of S. chromogenes and S. simulans were similar in clinical and subclinical cases. Even though the number of isolates was small, the fact that $S$. hyicus was mainly found in clinical cases may indicate that this species is relatively virulent. This hypothesis is supported by the finding by Perry et al. (2010) that S. hyicus was uncommon among subclinical cases of mastitis, but that quarters infected with this species had very high somatic cell count (SCC). Moreover, in a study using phenotypic species differentiation S. hyicus was described as the most pathogenic CNS species (Myllys, 1995). That S. epidermidis and S. saprophyticus were mainly found in subclinical cases may indicate that they are less virulent and/or cause more persistent infections than other CNS. In line with this hypothesis, Thorberg et al. (2009) found that persistent $S$. epidermidis IMI were common. In the same study, $S$. saprophyticus was only found in udder quarters with relatively low SCC indicating a

211 minor effect on udder health.

$213 \beta$-lactamase production is the most common resistance mechanism in staphylococci.

214 Overall, such production was more prevalent among subclinical CNS isolates than in 215 clinical isolates, which is in line with a Norwegian study (Jarp, 1991). Taponen et al. 
216 (2006) found a similar numerical, but not significant, difference. The proportion of $\beta+$

217 subclinical CNS isolates (29\%) was similar to those reported from subclinical mastitis

218 or IMI in Finland (32\%), Norway (36\%) and Netherlands (37\%) (Pitkälä et al., 2004;

219 Østerås et al., 2006; Sampimon, 2009). The relatively low proportion of $\beta+$ clinical

220 isolates supports the Swedish veterinary policy of benzyl penicillin as the first drug of

221 choice in clinical CNS mastitis.

222

The marked difference between CNS species in $\beta$-lactamase production is an important

finding. Among the most frequently isolated species, such production was common in $S$.

epidermidis and S. haemolyticus, but not in S. chromogenes and S. simulans. These

results are in line with Sampimon (2009) who found that resistance to penicillin was

$70 \%, 33 \%, 18 \%$ and $0 \%$ in S. epidermidis, S. haemolyticus, S. chromogenes and S.

simulans, respectively. Similar proportions of $\beta$-lactamase production for S. epidermidis

$(46 \%)$ and S. chromogenes (18\%) was also reported in a US study (Sawant et al., 2009).

In that study, however, phenotypic species identification was performed.

The results indicate that the higher proportion of penicillin resistance in subclinical than in clinical isolates was due to the high prevalence of S. epidermidis in subclinical mastitis in combination with a high proportion of resistance among less common species such as S. saprophyticus, S. warneri/pasteuri and S. xylosus.

Overall, resistance to other antimicrobials than penicillin was uncommon, and was markedly lower than in other studies for example for erythromycin, oxacillin and tetracycline (Lüthje and Schwarz, 2006; Rajala-Schultz et al., 2009; Sampimon, 2009; 
expressed resistance to more than one antimicrobial compound. Differences between

242 CNS species in antimicrobial susceptibility have also been observed. Both Sampimon

243 (2009) and Sawant et al. (2009) found that S. epidermidis exhibited lower susceptibility

244 to several antimicrobials than other species. Sampimon (2009) found for example that

245 the mecA gene, i.e. methicillin resistance, was significantly more common in $S$.

246 epidermidis than in other species.

248 In line with the results for $\beta$-lactamase, trimethoprim resistance differed between CNS species. A majority of the resistant isolates was $S$. simulans or $S$. haemolyticus. The reasons behind differences in antimicrobial susceptibility between species are not known. It may be hypothesized that the resistant isolates belonged to the same clonal group within each species, and that this group also inhabit virulence factors important for spread of infection. Thus, further genotypic analyses of differences within species are needed.

Care should be taken when comparing different studies as study design and methodology, including definitions of mastitis, may vary.

\section{Conclusion}

In conclusion, the distribution of CNS species differed between clinical and subclinical mastitis indicating inter-species variation of pathogenicity and epidemiology. Overall, the prevalence of antimicrobial resistance was low, but some variation between CNS species, especially in $\beta$-lactamase production, was observed. 
The authors thank the Swedish Farmers' Foundation for Agricultural Research and the Swedish Board of Agriculture for financial support.

268

269

\section{References}

270

Bengtsson, B., Ericsson Unnerstad, H., Ekman, T., Artursson, K., Nilsson-Öst, M.,

Persson Waller, K., 2009. Antimicrobial susceptibility of udder pathogens from cases of acute clinical mastitis in dairy cows. Vet. Microbiol. 136, 142-149.

Bryan, L., Godfrey, A., 1991. Beta-lactamase antibiotics: mode of action and bacterial resistance. In: Lorian, V. (Ed.). Antibiotics in Laboratory Medicine. William and Wilkins, Baltimore, USA, p. 648.

Capurro, A., Artursson, K., Persson Waller, K., Bengtsson, B., Ericsson Unnerstad H., Aspán, A., 2009. Comparison of a commercialized phenotyping system, antimicrobial susceptibility testing, and tuf gene sequence-based genotyping for species-level identification of coagulase-negative staphylococci isolated from cases of bovine mastitis. Vet. Microbiol. 134, 327-333.

Ericsson Unnerstad, H., Lindberg, A., Persson Waller, K., Ekman, T., Artursson, K.,

Nilsson-Öst, M., Bengtsson, B., 2009. Microbial aetiology of acute clinical mastitis and agent-specific risk factors. Vet. Microbiol. 137, 90-97.

Hogan, J.S., González, R.N., Harmon, R.J., Nickerson, S.C., Oliver, S.P., Pankey, J.W.,

Council, Verona, WI.

Jarp., J. 1991. Classification of coagulase-negative staphylococci isolated from bovine clinical and subclinical mastitis. Vet. Microbiol. 27, 151-158. 
Koivula, M., Pitkälä, A., Pyörälä, S., Mäntysaari, E.A., 2007. Distribution of bacteria and seasonal and regional effects in a new database for mastitis pathogens in Finland. Acta Agricult. Scand. A 57, 89-96.

292

Lüthje, P., Schwartz, S., 2006. Antimicrobial resistance of coagulase-negative staphylococci from bovine subclinical mastitis with particular reference to macrolidelincosamide resistance phenotypes and genotypes. J. Antimicrob. Chemother. 57, 966969.

Myllys, V., 1995. Staphylococci in heifer mastitis before and after parturition. J. Dairy Res. 62, 51-60.

Østerås, O, Sølverød, L., Reksen, O., 2006. Milk culture results in a large Norwegian survey - effects of season, parity, days in milk, resistance, and clustering. J. dairy Sci. 89, 1010-1023.

Perry, J., Middleton, J.R., Dufour, S., Scholl, D., Calloway, C., Anderson, S., Dohoo. I., 2010. Association of coagulase negative staphylococcal species and milk somatic cell count of cows from the Canadian national cohort of dairy farms. NMC Annual Meeting Procedures, Albuquerque, New Mexico, 204-205.

Pitkälä, A., Haveri, M., Pyörälä, S. Myllys, V., Honkanen-Buzalski, T., 2004. Bovine mastitis in Finland 2001 - prevalence, distribution of bacteria, and antimicrobial resistance. J. Dairy Sci. 87, 2433-2441.

Pyörälä, S., Taponen, S. 2009. Coagulase-negative staphylococci - Emerging mastitis pathogens. Vet. Microbiol. 134, 3-8.

310 Rajala-Schultz, P.J., Torres, A.H., DeGraves, F.J., Gebreyes, W.A., Patchanee, P., 2009.

311 Antimicrobial resistance and genotypice characterization of coagulase-negative

312 staphylococci over the dry period. Vet. Microbiol. 134, 55-64. 
313 Sampimon, O.C., 2009. Coagulase-negative staphylococci mastitis in Dutch dairy herds.

314 Thesis, Dutch Animal Health Serive (GD), Deventer, The Netherlands.

315 Sampimon, O.C., Barkema, H.W., Berends, I.M.G.A., Sol, J., Lam, T.J.G.M., 2009.

316 Prevalence and herd-level risk factors for intramammary infection with coagulase-

317 negative staphylococci in Dutch dairy herds. Vet. Microbiol. 134, 37-44.

318 Sawant, A.A., Gillespie, B.E., Oliver, S.P., 2009. Antimicrobial susceptibility of

319 coagulase-negative Staphylococcus species isolated from bovine milk. Vet. Microbiol.

$320134,73-81$.

321 Smyth, RW., Kahlmeter, G., Liljequist, BO., Hoffman, B., 2001. Methods for

322 identifying methicillin resistance in Staphylococcus aureus. J. Hosp. Inf. 48, 103-107.

323 Taponen, S., Simojoki, H., Haveri, M., Larsen, H.D., Pyörälä, S., 2006. Clinical

324 characteristics and persistence of bovine mastitis caused by different species of

325 coagulase-negative staphylococci identified with API or AFLP. Vet. Microbiol. 115,

326 199-207.

327 Taponen, S., Björkroth, J., Pyörälä, S., 2008. Coagulase-negative staphylococci isolated

328 from bovine extramammary sites and intramammary infections in a single dairy herd. J.

329 Dairy Res. 75, 422-429.

330 Thorberg, B.-M., Danielsson-Tham, M.-L., Emanuelson, U., Persson Waller, K., 2009.

331 Bovine subclinical mastitis caused by different types of coagulase-negative

332 staphylococci. J. Dairy Sci. 92, 4962-4970.

333 Zadoks, R.N., Watts, J.L., 2009. Species identification of coagulase-negative

334 staphylococci: Genotyping is superior to phenotyping. Vet. Microbiol. 134, 20-28. 
1 Table 1. Composite SCC (cells/ml) inclusion criteria for cows in the survey on

2 subclinical mastitis

\begin{tabular}{lll}
\hline Category & Latest monthly test milking & Previous monthly test milking
\end{tabular}

New infection $\quad \geq 200000 \quad<100000$

Chronic infection $\quad>300000 \quad>300000$

3 
4 Table 2. Prevalence of CNS in acute clinical (Ericsson Unnerstad et al., 2009) and

5 subclinical (new/chronic infection) mastitis when including all cases or only cases with

6 specific infection i.e. excluding samples with no growth and contaminated samples

Type of mastitis

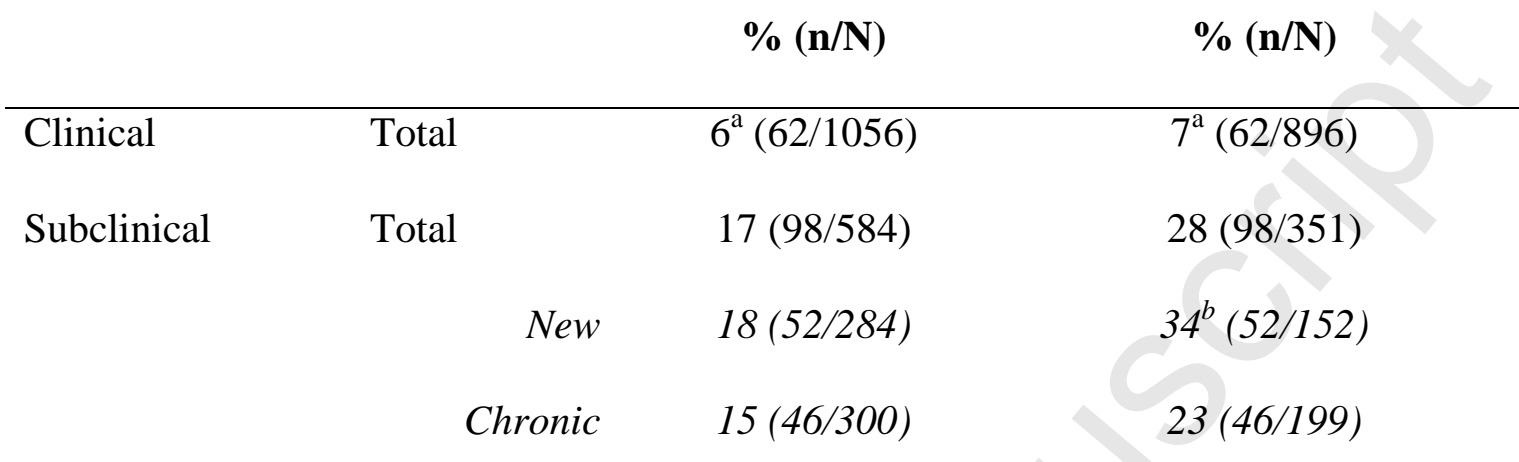

${ }^{\mathrm{a}}$ Significantly different $(\mathrm{P}<0.001)$ from total subclinical mastitis within column.

$8 \quad{ }^{\mathrm{b}}$ Significantly different $(\mathrm{P}=0.022)$ from chronic subclinical mastitis within column. 
Table 3. Distribution of CNS species among isolates from cases of acute clinical mastitis (CM), and cases of subclinical mastitis (SCM; new and chronic infection), and numbers $(\%)$ of isolates producing $\beta$-lactamase $(\beta+)$ within species

\begin{tabular}{|c|c|c|c|c|c|c|c|c|c|c|}
\hline \multirow[t]{4}{*}{ Species } & \multicolumn{2}{|c|}{ CM } & \multicolumn{6}{|c|}{ SCM } & \multicolumn{2}{|c|}{ Total } \\
\hline & \multirow[b]{3}{*}{$\begin{array}{c}n \\
(\%)\end{array}$} & \multirow{3}{*}{$\begin{array}{c}\beta+ \\
\mathbf{n} \\
(\%)\end{array}$} & \multicolumn{2}{|c|}{ New } & \multicolumn{2}{|c|}{ Chronic } & \multicolumn{2}{|c|}{ Total SCM } & \multirow{2}{*}{\multicolumn{2}{|c|}{$\beta+$}} \\
\hline & & & & $\beta+$ & & $\beta+$ & & $\beta+$ & & \\
\hline & & & $\begin{array}{c}\mathbf{n} \\
(\%)\end{array}$ & $\begin{array}{c}n \\
(\%)\end{array}$ & $\begin{array}{c}\mathbf{n} \\
(\%)\end{array}$ & $\begin{array}{c}n \\
(\%)\end{array}$ & $\begin{array}{c}\mathbf{n} \\
(\%)\end{array}$ & $\begin{array}{c}n \\
(\%)\end{array}$ & $\begin{array}{c}n \\
(\%)\end{array}$ & $\begin{array}{c}n \\
(\%)\end{array}$ \\
\hline S. arlettae & 0 & - & $\begin{array}{c}1 \\
(2)\end{array}$ & 1 & $\begin{array}{c}1 \\
(2)\end{array}$ & 1 & $\begin{array}{c}2 \\
(2)\end{array}$ & 2 & $\begin{array}{c}2 \\
(1)\end{array}$ & 2 \\
\hline S. aureus ${ }^{\mathrm{d}}$ & $\begin{array}{c}2 \\
(4)\end{array}$ & 1 & 0 & - & 0 & - & 0 & & $\begin{array}{c}2 \\
(1)\end{array}$ & 1 \\
\hline $\begin{array}{l}\text { S. chromo- } \\
\text { genes }\end{array}$ & $\begin{array}{c}16 \\
(29)\end{array}$ & $\begin{array}{c}1 \\
(6)\end{array}$ & $\begin{array}{c}9 \\
(17)\end{array}$ & $\begin{array}{c}0 \\
(0)\end{array}$ & $\begin{array}{c}12 \\
(26)\end{array}$ & $\begin{array}{c}2 \\
(17)\end{array}$ & $\begin{array}{c}21 \\
(21)\end{array}$ & $\begin{array}{c}2 \\
(10)\end{array}$ & $\begin{array}{c}37 \\
(24)\end{array}$ & $\begin{array}{c}3^{c} \\
(8)\end{array}$ \\
\hline $\begin{array}{l}\text { S. epidermi- } \\
\text { dis }\end{array}$ & $\begin{array}{l}4^{\mathrm{a}} \\
(7) \\
\end{array}$ & 2 & $\begin{array}{c}17 \\
(33)\end{array}$ & $\begin{array}{c}99 \\
(53)\end{array}$ & $\begin{array}{c}13 \\
(28) \\
\end{array}$ & $\begin{array}{c}3 \\
(23) \\
\end{array}$ & $\begin{array}{c}30 \\
(31) \\
\end{array}$ & $\begin{array}{c}12 \\
(40)\end{array}$ & $\begin{array}{c}34 \\
(22) \\
\end{array}$ & $\begin{array}{c}14 \\
(41)\end{array}$ \\
\hline S. gallinarum & 0 & - & $\begin{array}{c}1 \\
(2)\end{array}$ & 1 & $\begin{array}{c}1 \\
(2)\end{array}$ & 1 & $\begin{array}{c}2 \\
(2)\end{array}$ & 2 & $\begin{array}{c}2 \\
(1)\end{array}$ & 2 \\
\hline $\begin{array}{l}\text { S. haemolyti- } \\
\text { cus }\end{array}$ & $\begin{array}{c}8 \\
(14)\end{array}$ & $\begin{array}{c}2 \\
(25) \\
\end{array}$ & $\begin{array}{c}8 \\
(15)\end{array}$ & $\begin{array}{c}4 \\
(50) \\
\end{array}$ & $\begin{array}{c}6 \\
(13) \\
\end{array}$ & $\begin{array}{c}3 \\
(50) \\
\end{array}$ & $\begin{array}{c}14 \\
(14)\end{array}$ & $\begin{array}{c}7 \\
(50)\end{array}$ & $\begin{array}{c}22 \\
(14)\end{array}$ & $\begin{array}{c}9 \\
(41) \\
\end{array}$ \\
\hline S. hyicus & $\begin{array}{c}6^{\mathrm{a}} \\
(11) \\
\end{array}$ & $\begin{array}{c}0 \\
(0)\end{array}$ & 0 & & $\begin{array}{l}1 \\
(2)\end{array}$ & 0 & $\begin{array}{c}1 \\
(1)\end{array}$ & 0 & $\begin{array}{c}7 \\
(5) \\
\end{array}$ & $\begin{array}{c}0 \\
(0)\end{array}$ \\
\hline S. lentus & $\begin{array}{c}1 \\
(2)\end{array}$ & 1 & 0 & & 0 & - & 0 & - & $\begin{array}{c}1 \\
(<1)\end{array}$ & 1 \\
\hline $\begin{array}{l}\text { S. pseud- } \\
\text { intermedius }\end{array}$ & 0 & - & $\begin{array}{l}1 \\
(2)\end{array}$ & 1 & 0 & - & $\begin{array}{c}1 \\
(1)\end{array}$ & 1 & $\begin{array}{c}1 \\
(<1)\end{array}$ & 1 \\
\hline $\begin{array}{l}\text { S. sapro- } \\
\text { phyticus }\end{array}$ & $0^{\mathrm{b}}$ & - & $\begin{array}{l}4 \\
(8)\end{array}$ & 3 & $\begin{array}{c}3 \\
(7)\end{array}$ & 3 & $\begin{array}{c}7 \\
(7)\end{array}$ & $\begin{array}{c}6 \\
(86)\end{array}$ & $\begin{array}{c}7 \\
(5)\end{array}$ & $\begin{array}{c}6 \\
(86)\end{array}$ \\
\hline S. simulans & $\begin{array}{c}14 \\
(25)\end{array}$ & $\begin{array}{c}0 \\
(0)\end{array}$ & $\begin{array}{c}6 \\
(12)\end{array}$ & $\begin{array}{c}0 \\
(0)\end{array}$ & $\begin{array}{c}7 \\
(15)\end{array}$ & $\begin{array}{c}0 \\
(0) \\
\end{array}$ & $\begin{array}{c}13 \\
(13)\end{array}$ & $\begin{array}{c}0 \\
(0)\end{array}$ & $\begin{array}{c}27 \\
(18)\end{array}$ & $\begin{array}{l}0^{c} \\
(0)\end{array}$ \\
\hline S. sp. & 0 & - & $\begin{array}{c}1 \\
(2)\end{array}$ & 0 & 0 & - & $\begin{array}{c}1 \\
(1)\end{array}$ & 0 & $\begin{array}{c}1 \\
(<1)\end{array}$ & 0 \\
\hline $\begin{array}{l}\text { S. warneri/ } \\
\text { pasteuri }\end{array}$ & $\begin{array}{l}3 \\
(5)\end{array}$ & 0 & $\begin{array}{c}2 \\
(4)\end{array}$ & 2 & 0 & - & $\begin{array}{c}2 \\
(2)\end{array}$ & 2 & $\begin{array}{c}5 \\
(3)\end{array}$ & $\begin{array}{c}2 \\
(40) \\
\end{array}$ \\
\hline S. xylosus & $\begin{array}{c}2 \\
(3)\end{array}$ & 1 & $\begin{array}{c}2 \\
(4)\end{array}$ & 1 & $\begin{array}{c}2 \\
(4)\end{array}$ & 2 & $\begin{array}{c}4 \\
(4) \\
\end{array}$ & 3 & $\begin{array}{c}6 \\
(4)\end{array}$ & $\begin{array}{c}4 \\
(67) \\
\end{array}$ \\
\hline Total & $\begin{array}{c}56 \\
(100) \\
\end{array}$ & $\begin{array}{c}8^{\mathrm{a}} \\
(14) \\
\end{array}$ & $\begin{array}{c}52 \\
(100) \\
\end{array}$ & $\begin{array}{c}22 \\
(42) \\
\end{array}$ & $\begin{array}{c}46 \\
(100)\end{array}$ & $\begin{array}{c}15 \\
(33) \\
\end{array}$ & $\begin{array}{c}98 \\
(100) \\
\end{array}$ & $\begin{array}{c}37 \\
(38) \\
\end{array}$ & $\begin{array}{c}154 \\
(100) \\
\end{array}$ & $\begin{array}{c}45 \\
(29) \\
\end{array}$ \\
\hline
\end{tabular}

${ }^{\mathrm{a}}$ The prevalence was significantly different $(\mathrm{P}<0.05)$ from total SCM within row (based on 94 cases of SCM, see Statistical analyses).

${ }^{\mathrm{b}}$ The prevalence tended to differ $(0.05>\mathrm{P}<0.10)$ from total $\mathrm{SCM}$ within row (based on 94 cases of SCM, see Statistical analyses).

${ }^{\mathrm{c}}$ The prevalence was significantly different $(\mathrm{P}<0.05)$ from that of $S$. epidermidis and $S$.

18 haemolyticus within column (based on 94 cases of SCM, see Statistical analyses).

$19{ }^{\mathrm{d}}$ The strains were coagulase-negative. 